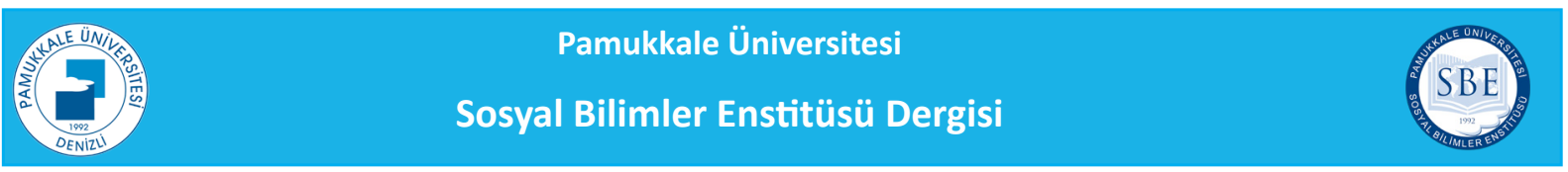

Pamukkale University Journal of Social Sciences Institute

ISSN 1308-2922 E-ISSN 2147-6985

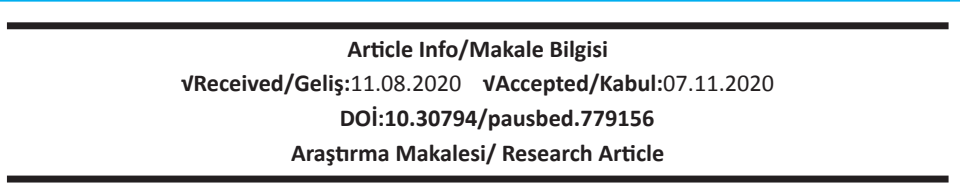

Güntay, V. (2021). "Rethinking The Global Politics and Leadership: Ulrich Beck's Risk Society Versus Postmodern Politics" Pamukkale Üniversitesi Sosyal Bilimler Enstitüsü Dergisi, Sayı 44, Denizli, ss. 405-418.

\title{
RETHINKING THE GLOBAL POLITICS AND LEADERSHIP: ULRICH BECK'S RISK SOCIETY VERSUS POSTMODERN POLITICS
}

\author{
Vahit GÜNTAY*
}

\begin{abstract}
Ulrich Beck, with the conceptualization of risk society and in his book, entitled "Risk Society" in 1992, claims that the postmodern era gave birth to a social structure adorned with risks. This situation, which arises mainly from the problem of trust, actually presents a model of society in which the silent motto of individualism and capitalism prepared by modernity. On the other hand, there is no consensus in the definitions of postmodernism, which is a widely discussed concept since the mid-20th century. However, postmodernism corresponds to situations such as globalization, heightened consumption, a change of the centralist state understanding, the commodification of knowledge, and a deformation in lifestyle. Social control mechanisms and the limitations, as Beck stated, nurture this belonging from their former strength. The melting state, which can be observed at different scales in every society, becomes more visible along with some developments. Globalization and mobility, the increased complexity of education and business life, the erosion of the cyber realm and the mechanism of law are just a few areas, underlined in the present trial. In the context of this study, Ulrich Beck's concept will be compared with postmodernism and the question of whether postmodernism and the change in global policy understanding will ensure the continuity of international politics and relations.
\end{abstract}

Keywords: Ulrich Beck, Risk Society, Modernism, Postmodernism, Global Politics.

\section{KÜRESEL SIYASETi VE LIDERLIĞi YENIDEN DÜŞÜNMEK: ULRICH BECK'IN RISK TOPLUMU KARŞISINDA POSTMODERN POLITIKALAR}

Öz

Ulrich Beck, 1992 yılındaki risk toplumu kavramsallaştırması ve "Risk Topluluğu" başlıklı kitabıyla, postmodern dönemin risklerle bezenmiş bir sosyal yapı doğurduğunu ileri sürmektedir. En başta güven sorunundan kaynaklanan bu durum, gerçekte modernizm tarafindan hazırlanan bireycilik ve kapitalizmin sessiz sloganının olduğu bir toplum modeli sunar. Öte yandan, 20. yüzyılın ortalarından beri yaygın olarak tartışılan postmodernizmin tanımlarında da netlik yoktur. Bu yönüyle postmodernizmin küreselleşme, tüketim, devletçi düzeylerde merkezi anlayışın değişmesi, bilginin metalaştrılması ve yaşam biçimindeki deformasyon gibi durumlara karşılık geldiği söylenebilir. Beck'in belirttiği gibi, toplumsal denetim mekanizmalarındaki sınırlamalar, modernizmin eski güç formundan gelenlerle beslenmektedir. Her toplumda farklı ölçeklerde görülebilen bu değişim artık daha belirginleşmiştir. Küreselleşme ve hareketlilik, eğitim ve iş yaşamının karmaşıklaşması, siber alanın erozyonu ve hukuk mekanizması gibi konular bu değişimin tartışılığı alanlardan sadece birkaçıdır. Bu çalışma bağlamında Ulrich Beck'in kavramından yola çıkılarak, postmodernizm ve küresel politika anlayışındaki değişimin uluslararası politikadaki sürekliliği sağlayıp sağlayamayacağı sorunsalı tartışılmıştır.

Anahtar Kelimeler: Ulrich Beck, Risk Toplumu, Modernizm, Postmodernizm, Küresel Politikalar.

* Dr. Öğr. Üyesi, Karadeniz Teknik Üniversitesi, İktisadi ve İdari Bilimler Fakültesi, Uluslararası İlişkiler Bölümü, TRABZON.

e-posta: vahit.guntay@ktu.edu.tr (https://orcid.org/0000-0003-0645-8023) 


\section{INTRODUCTION}

As a sociologist, Ulrich Beck introduced the risk society concept to the social sciences to understand better the social problems in today's societies. Beck (1992a) argues that the risk society is a product of modernization. Therefore, he thinks that the risks, dangers, and threats, faced by contemporary societies are side effects of modernity. Beck also states that reflexive modernization could provide a solution to the social problems that arise from the modern world.

The concept of risk in a modern sense emerged with the influence of geographical discoveries in the 15th and 16th centuries. With the discovery of new places over time, space factor has been added to the concept of risk. Nowadays, there is also a time factor in the definition of risk. With the addition of the time factor into the risk's definition, the human dimension of risk has expanded. Therefore, the human factor has been added to the definition of the risk concept. Globalization, capitalism, terrorism, and all kinds of threats that concern human beings express the human aspect of risk coverage.

Global structures in almost every field have started to direct individuals and societies towards a common point. It is quite challenging to stay out of this new restructuring. Every stage of national and international plans has emerged as postmodernism. The new capitalist structure in the world, new markets and the creation of new consumers for these markets, or every step acted towards expanding the existing ones. Integration and organization activities of multinational companies with economic and political power have emerged from these steps.

While postmodernism is a general fixation, Ulrich Beck (1992a) states that a risk environment has spread to almost all societies in the late modern world so that each individual grows within the risk society. One of the first areas where risk arises, is the process of education beside social inclusion or exclusion. Educational processes are gradually evolving into a complex structure in the late modern period and in the higher level, in the hierarchy of needs process along the life. Furthermore, Beck (1992a) states that "As schooling increases, traditional orientations, ways of thinking and lifestyles are reshaped and replaced by universal forms of learning and teaching, as well as universal forms of knowledge and language." This idea invites one to rethink the global world, policies and postmodernism.

In this study, which is planned to be a representative experiment, a comparison of the risk society and postmodernism phenomenon will be made in the first place. Then, the conceptualization of risk society will be discussed in further detail. As a fundamental claim of the study, the theoretical view of the correlation between risk society and postmodernism will be evaluated. In doing so, changes in political developments and understanding of global society will be considered as mediating variables.

\section{METHODOLOGY PROBLEM IN COMPARISON OF RISK SOCIETY AND POSTMODERNISM}

With modernism, man remains a supreme being rather than a critical, questioning subject. The areas where this transformation is evaluated, are shaped by power and authority. One of the criticisms of modernism concerns its central idea that the West is the sole representative of civilization (Thompson, 2018). The East and the West, the traditional and the modern contradictions express another perspective that is opposed to the ignorance of non-Western cultures. ${ }^{1}$

The most systematic and consistent criticism of enlightenment and modernism comes from the Frankfurt School's leading thinkers, such as Max Horkheimer and Theodor W. Adorno. The book entitled, The Dialectics of Enlightenment, which they co-authored is a manifesto written against the philosophical and cultural foundations of modernism (Miller, 2014). Sociological and political methodology lack the critique of postmodernism in terms of data with these cumulative criticisms. The starting point of the postmodern critique of modernism is the singularity caused by modernism. ${ }^{2}$ For example, thinkers, such as Jean-François Lyotard and Zygmunt Bauman

1 Modernism has a positive aspect. Factual science attempts to obtain predictive and explanatory information about the external world. In order to do this, theories are based on highly general propositions expressing normal relations in the external world through factuality, systematic observation and experimentation.

2 The traditional or classical understanding of governance has placed great importance on rationality, efficiency and hierarchical control. In 
emphasize the importance of differences, plurality and identities against singularity. For them, there is no single version of the truth, justice, and democracy (Baudrillard, 1998). The real purpose of postmodernists is to deconstruct institutions and concepts that have been established together with modernism (Hoy, 1993).

The controversial situation of the postmodernism concept stems from the fact that philosophers from different perspectives assign different meanings to the concept. The concept was used in art, painting and architecture from the 1960 s to the 1980 s, and it influenced philosophy and sociology disciplines, as well as social movements (Turnbul, 2010). In the 1980s, postmodernism continued to achieve new meanings despite having some fundamental changes in different parts of the world. During this period, when the effects of globalization are felt very quickly, economic developments triggered the search for new styles in production (Matthewman and Hoey, 2006). When the recent period's changes are considered, it becomes interesting to compare the concepts of risk society and postmodern society. ${ }^{3}$

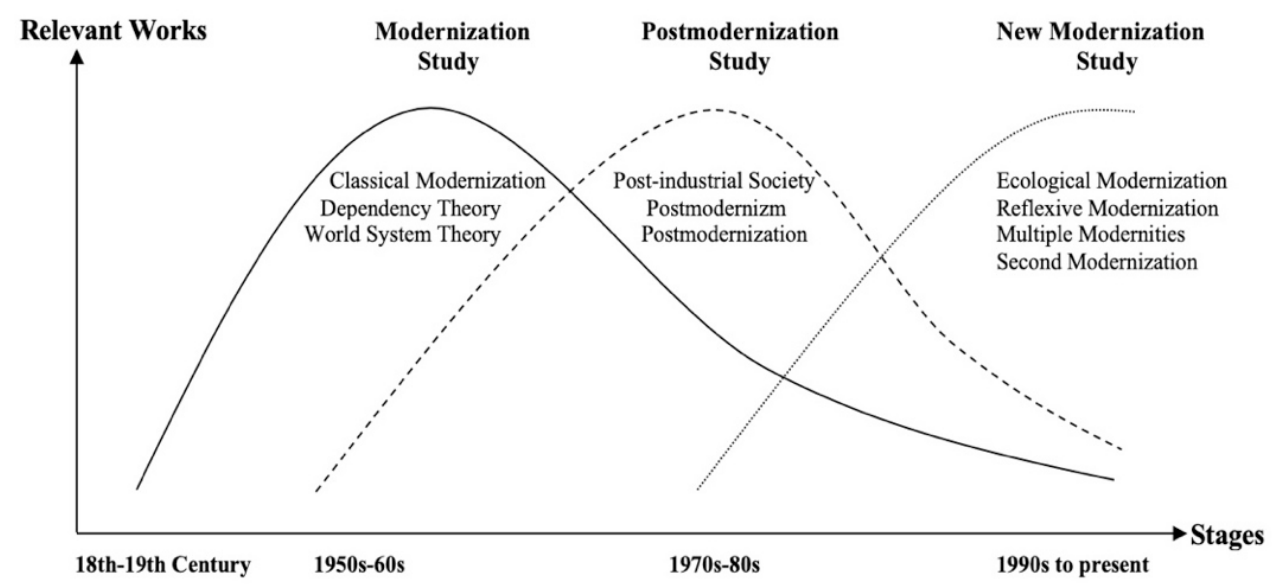

Figure 1. Three Waves of Modernization Studies in the $20^{\text {th }}$ Century

Source: He, 2015.

Postmodernist theorist Jean François Lyotard (1984) sees postmodernism as a periodical differentiation or break from modernism and the birth of a new social formation. Although descriptive discourses cannot be developed, postmodernism continues to be enriched with new meanings. It is essential to frame the process of how postmodernism is accepted as a break from modernism. The concept of risk society has a different stance methodologically (Huyssen, 2006). The aim of this research is to understand global politics or society through a comparison of postmodernism and risk society.

\section{IS RISK SOCIETY IN THE FACE OF POSTMODERNISM?}

Beck (1992a) considers the risk society as a process in which two separate societies are intertwined. That explains two separate societies in two stages. First, threats emerged, but they are not the subject of political conflicts. Second, institutions within industrial society become producers of these hazards and it is almost impossible to control these institutions. Beck (1992b) adopts the German tradition of modernity. For this reason, Beck argues that modernity is not over; but it is still ongoing. Therefore, he thinks differently about postmodernism or change. ${ }^{4}$ Beck sees the risk society as a result of the modernization process that must be experienced, and which cannot be avoided. Therefore, individuals and societies face many risks and dangers consciously or unconsciously. In this case, Beck says that measures should be taken instead of avoiding risks and

the modern age, management relied on the facts, presented by science to develop and legalize its policies.

3 Modernism is a cultural transformation project in the context of improving the individual's ability to judge and criticize. In this respect, modernism is an intellectual effort. On the other hand, modernism had a theoretical content and it had been widespread and dominant in the political structure and social life since the 18 th century.

4 According to Mirchandani (2005), risk society is associated with the postmodern or late modern society. Risk society indicates a significant transformation in modern or industrial society. Within this concept, it does not necessarily mean that the current social life is riskier than before by its nature. However, it is underlined that risk enters into many new areas of our social life and social actors now have to think and organize the world according to risk. 
dangers. ${ }^{5}$ Yet, according to Beck, it is not right to accept every innovation directly without questioning (Williams, 2008). Therefore, individuals should be informed about risks and uncertainties that surround in the world.

Considering individuals' critical thinking in the risk society, Beck developed a reflexive modernization theory that Anthony Giddens also developed further. Reflexive modernization is a theory of advanced modernity for understanding and explaining recent social changes within the framework of risk society in an advanced stage, pointing to the essential repeatability and continuity of modernity in line with the parameters of reflexive sociology (Alexander and Smith, 1996). The social theoreticians also term this paradigm as the new era of modernity, which begun in the 1960s and continues to change gradually (Matthewman and Hoey, 2006).

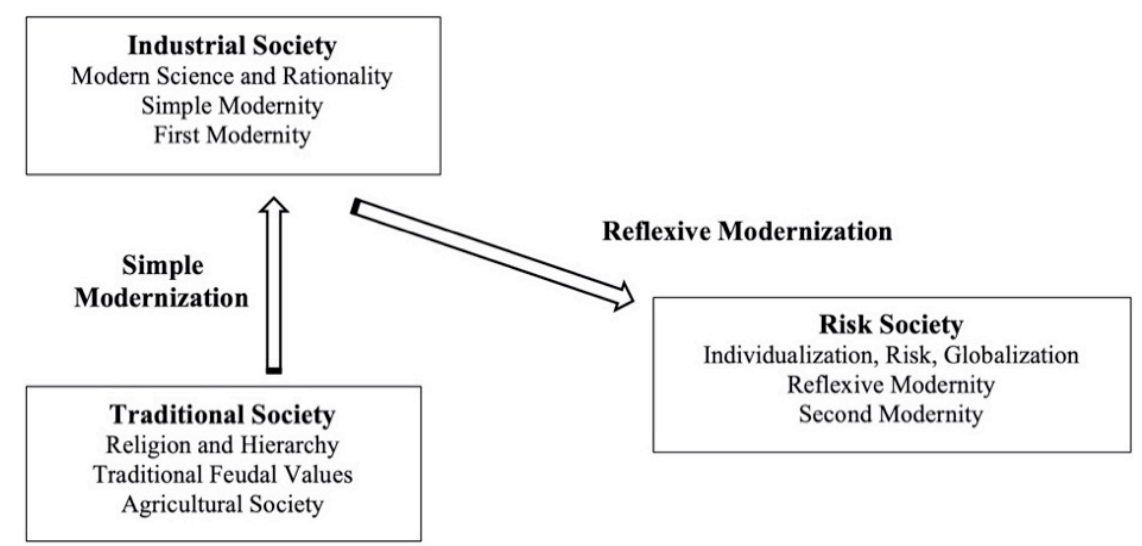

Figure 2. Society Changes and Reflexive Modernization

Source: He, 2012.

Globalization as a relatively more recent concept than reflexive modernization became popular in the 1990 s. Globalization plays an active role in every field and brings with it its dilemmas (Mittelman, 2004). Beck describes the concept of globalization as a state of not being tied to any state or government. Moreover, according to Beck (2000), there is no border between countries following globalization. Therefore, there is higher interaction between societies and cultures. Globalization causes chaos in the economic, cultural and religious spheres in the World. Beck (2000) claims that risk has also become a global actor from the early days of the risk society. ${ }^{6}$ Beck's risk society corresponds to a process of modernity, in which the legitimacy and spread of risks have become more dangerous, and the industrial society has become a risk society as a result of insufficient control and security mechanisms.

Industrial capitalism entered a severe crisis in the era of globalization and became the first precursor of the change in the 1970s (Kellner, 2002). Speed, globalization and the disappearance of boundaries in information and communication technologies have created a new social structure which is named as an information society. This new social structure, which developed beyond the industrial society, has been described as post-industrial society in the late capitalism (Perelman, 2015). The process is also conceptualized as fordism and postfordism based on production. ${ }^{7}$

The processes of these social changes can be observed in infrastructures and superstructures. According to these changes, while the sub-code of a postmodernist structural change constitutes the fordist and postfordist mode of production, the upper limit of the change is provided by modernist and postmodernist structural

5 Ulrich Beck's risk society and self-reflecting modernization theory will play a vital role in the understanding of contemporary Western sociology and societies together with other sociological concepts of today. Beck tries to explain the stage in which Western societies live through the theory of risk society.

6 The risk society is not considered separately from industrial society. Beck sees modernization as a process of development and progress. In the process of modernization, a new social definition is now obsolete by accepting the indicated industrial society.

7 The West, which is in the stage of risk society or the post-industrial society as in Beck's definition, wants to partner other societies as long as they live. Societies, agricultural societies or industrial societies show different characteristics and different historical development lines in the World and they are seen as familiar to the advantages of modernization as well as their negativities. Despite the regular opportunities brought by technology, societies are unaware of all these developments' environmental destruction, nuclear accidents and wars. For this reason, Beck's risk society can also be defined as the transformation of industrial society into having a global dimension. 
revisions (Goodchild, 1990). Therefore, the updates in the form of production do not only bring about an economic change, but they also provide mobility in social, political and cultural life.

Habermas' approach to modernity as an incomplete project is an essential reference for critics of postmodernism. One of the other radical criticisms against postmodernism is brought by Giddens. According to Giddens (1990), instead of dealing with concepts and terms such as postmodernism, it is necessary to look at the nature of modernity itself, which has been poorly understood in social sciences for specific reasons. Some thinkers criticize postmodernism for its conceptual characterizations. According to Heller and Feher (1988), postmodernism is not a new age or time change. Postmodernism is trying to uncover the dilemmas of modernism or it is a parasite which who tries to nurture from modernism's achievements. Furthermore, some interpret postmodernism as a revolt against the modernity project. Giddens (1992) uses the concept of radicalized modernism in response to these ideas that advocate postmodernism.

According to Beck (2005), risk society is pushing individuals for making confident choices in the process of modernization and globalization, in the elimination of social problems. From this point of view, Beck says that social problems should be accepted as a total rather than individuals' preference. With the risk society, globalization and the boomerang effect, the limits of threats and dangers are disappearing. Therefore, he (1992b) claims that the perpetrator and the victim will eventually be the same person, who faces the effects of risks, dangers and uncertainties that occur in the risk society. ${ }^{8}$

Beck (1992b) blames and criticizes politicians and engineers for the emergence of risks. Sociologists cannot put society in an experimental tube and examine it, and engineers cannot turn the world into a laboratory. The safety theories of nuclear reactors can only be learned after they have been installed, not before, and Beck criticizes engineers for their research techniques in the name of humanity. It is essential to keep in mind that risk society, modernism and postmodernism discourses in politics are for adapting the Western policies. Although the rhetoric of modernism and postmodernism seems to be global, it is not for the US and European countries, but for the East and the third world (Tushnet, 1995). It relieves itself in terms of its relations with the Eastern US and Europe. ${ }^{9}$ Discourses placed in the subconscious of the masses are very crucial for this process (Brocková, 2000). These discourses direct the masses towards a goal. First of all, the Eastern and Third World people who are always under control with Western admiration have entered the pot of global politics under modern lifestyle and postmodern point of view.

Throughout the history, projects for governing the East have been carried out behind several discourses that acted as passwords, and this process still continues in today's global politics (Brocková, 2000). The ageing of the political modernization process in the Third World countries and the inability to respond the international policies in the global sense caused a new process to begin. Although the process of modernization was developed by the West, it has lost its validity today and has been replaced by the discourse of postmodernism (Aronowitz, 1989). According to Tushnet (1995), although postmodernism is not a political tendency, it is used in political approaches and actions. New approaches in politics have pushed governments for becoming more transparent, more sympathetic and more pluralist. These approaches have brought international and global dimensions to national policies. ${ }^{10}$

The US and European countries have consistently seen and introduced their domestic and foreign policies as the upper-political system and the policies of the Eastern countries as the sub-political system. Although this promotion took a particular process for the West, which holds the mass media and technology, it was not too

\footnotetext{
8 The most significant difference between the risk society and the industrial society is seen as the emergence of risks as a result of the decisions taken in the society. It is accepted that external risks are not as effective as individual decisions. Apart from famines, natural disasters and epidemics, technological and scientific advances have been experienced, and definition of risk has attained different dimensions.

9 Jameson (2011) uses the term postmodern in a cultural as the cultural logic of multinational capitalism that corresponds to the third stage of capitalism. Establishing a relationship between the development of capitalism and cultural forms, Jameson divides capitalism into three stages: market capitalism, imperialist capitalism, and multinational capitalism. According to Jameson, market capitalism corresponds culturally to realism, while imperialist capitalism corresponds culturally to modernism.

10 While the late modern theorists deal with the new forms of politics, which they call life politics or sub-politics within the framework of the private sphere, they remain silent about how they are moved and politicized in the public sphere. However, the majority of postmodern theorists grasps politics of difference in the context of the public sphere and draws attention to how all the differences that are excluded from this sphere are politicized.
} 
tricky (Moraru, 2001). The East has been fascinated by the West in almost every field since the beginning of the 19th century. This process continues today. In the postmodern era, there is no need to visit the West, because of the communication technologies. The Eastern culture entered the pot of the West, whether it wanted to or not (Thompson, 2018). The postmodern discourse legitimized this situation among the Eastern societies. ${ }^{11}$

The underlying economic and political use of the postmodern discourse is in the cultural sphere. The fact that multinational corporations and states are in line with the aims of using the economic and political cultures of these societies for their benefit. These actors hold global power in their hands through the mass media, advertisements, public relations and regional experts (Seethi, 2001).

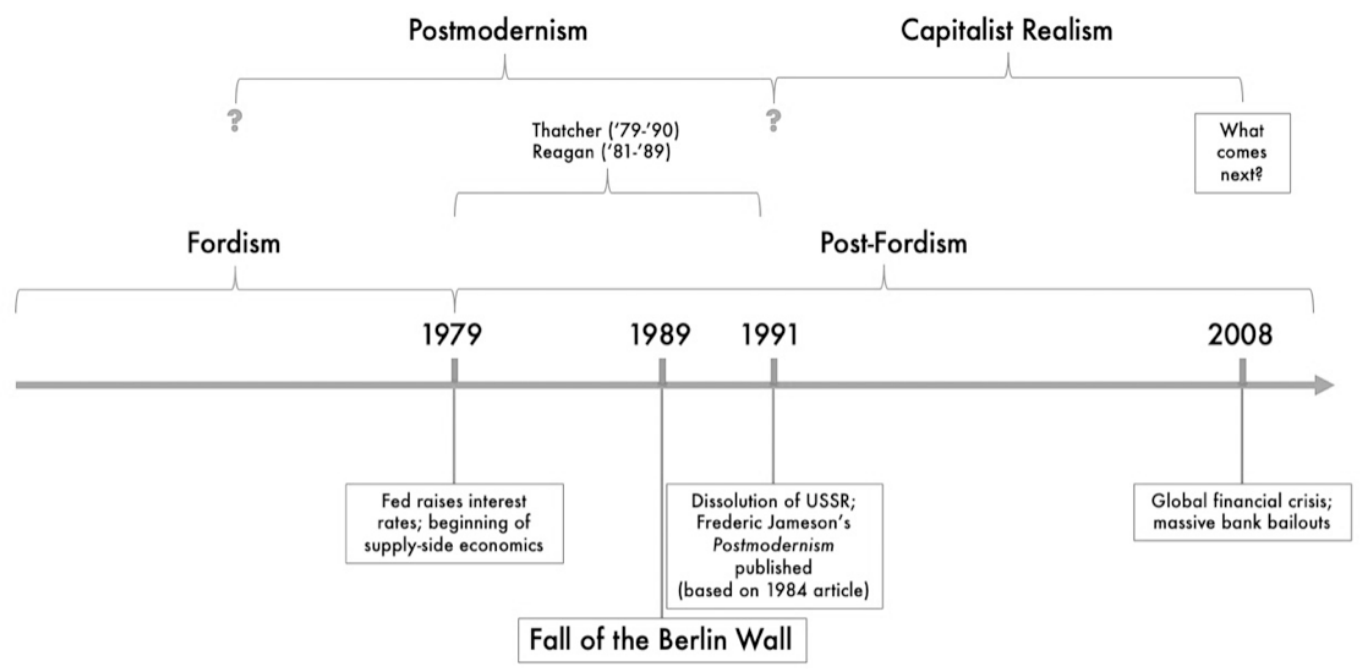

Figure 3. Mark Fisher's Timeline

Source: Libman, 2009.

This situation is precisely where individual and social trauma begin, and the same time, the social control mechanisms are surrounding the individual to erode in real terms. Control mechanisms determine the social affiliation of individuals, depending on the tradition and class parameters as Beck generally handled. In fact, as Van Loon states (2003), the risk society can be defined as a society in which a new form of alienated individual takes the stage.

In the risk society, commonly shared feelings have been transformed. To recall Beck's statement (1992a), need a partnership in the risk society has been replaced by concern partnership. For this reason, the social control mechanisms that direct individuals to the satisfaction of collective needs, have lost their influence and everyone has to fight on their own interests to become more visible. ${ }^{12}$

Eric Hobsbawm (2008) emphasizes that the free market globalization, which has already been established as a fashion, significantly increased economic and social inequalities between states and internationally. The determination that globalization has become fashionable draws attention to a crucial fact. ${ }^{13}$ It means that something has become fashionable, that it has spread rapidly and without question, and that it is generally affirmed with a cursory look (Leo, 2001). Once this approach is adopted, seeing the existence of negativity and digesting their reality require work and time. In this case, it is often too late to make return possible or largely eliminate these drawbacks.

11 In postmodern discourse, what holds a society together is not an ordinary consciousness or infrastructure. Individuals are the joints or positions, where such practices overlap. In this way, individuals can take part in many practices simultaneously. It follows that social identities are complex and heterogeneous.

12 In postmodernism, reality has a social basis, not objective. Reality is not a form that shapes rational people as in modernism, but a process based on relationships between people. Reality is not a given structure or category, but a process created by the experience of interaction. 13 When globalization is mentioned, it refers to a process that is directed not only by transnational actors pushing the role of nation-states to the background, but also a sociological formation like a world society in a network based on a political-ideological tendency. However, talking about globalization should not be perceived as talking about a phenomenon that has only positive results. 


\section{GLOBAL POLITICS ASPECT WITH THE FRAME OF RISK SOCIETY AND POSTMODERNISM}

The transition from modernity to postmodernity has clarified the problem of collective belonging. In the modern era, in terms of the state, nation, society or cultural existence; it was believed that individuals merged in common ideals and symbols, and they shared familiar tastes and common pride (Perelman, 2015). The emphasis on the excessive fragmentation and multiculturalism of society in the postmodern period has problematized this social integration and collective identity. ${ }^{14}$ Postmodernist theoreticians criticized the theories of modern society because these theories prioritized the interactions of the state, economy and culture within specific social organizations and relations (Goodchild, 1990). Even radical postmodernists saw social reality far from being identifiable and mappable (Best and Kellner, 1991). In this context, nationalism was dismissed as a reflection of cultural similarity in politics and an emphasis on the necessity of the nation's integrity and self-determination (Hirst and Thompson, 1999). However, some thinkers argued that postmodernism only addressed intellectuals and had no practical value and accused it of not suggesting a new system, but a continuum of the status quo (Atkinson, 2002). The same process applies to the scientific and cultural fields, structured by the paradigm of neoliberal capitalism. ${ }^{15}$ Postmodernism only plays the role of justifying this paradigm rather than reflecting a break (Fotopoulos, 2001).

In line with the holistic theorizing of the enlightenment tradition, which constitutes the intellectual basis of modernity, modern societies have been shaped based on unique interactions of state, economy and culture. ${ }^{16}$ The state is a pioneering will and power in regulating these interactions. It was a power that designed the modern state, and design meant differentiating between order and chaos. A typical example of this approach, which emphasizes similarity and uniformity, is the practice of citizenship (Bauman, 2007). In contrast, postmodern societies have been identified in line with defined by excessive fragmentation, and even these societies have been considered far from identifiable to their fragmentation.

In this context, while the social theory of the modern era becomes evident with the notions of consensus, order, system and integrity; postmodern social theory rejects all these approaches and emphasizes instead, the creation of the environmental conditions of maintaining and expressing the authenticity of difference in the social sphere (Aronowitz, 1989). The social reflection of this approach is that cultural and identity differences can coexist without sacrificing themselves. In this sense, the transition from modernity to postmodernity brought about a shift from inclusive categories, such as class and nation to identities, such as sexual groups, virtual groups and consumption groups (Heller and Feher, 1988).

Postmodernity is a culture and identity which is composed of randomly assembled pieces that do not have a totality of culture and rejects all hierarchical orders. The postmodernist theory of society seems to be far from providing satisfactory options for the provision and protection of rights in the socio-cultural spheres, as well as its libertarian approach (Atkinson, 2002). Moreover, postmodernism leaves the problems of how excessive social fragmentation contributes to human emancipation and paves the way for self-realization unsettled (He, 2012). Postmodern society does not have any solution or the means to offer to the individual in the face of problems that he cannot overcome with his internal dynamics. Postmodernists' emphasis on freedom and interpretation is far from being able to produce solutions in the realms of culture, identity and originality.

The postmodern criticism wants to open space for their new expansions and rebirths in order to position the difference and otherness within the modern and try to complement it (Thompson, 2018). Lyotard (1984) states that "The postmodern will advance what cannot be presented in the modern, in the presentation itself: it will deny a consensus of pleasure that makes it possible to share the consolation of beautiful forms and the collective nostalgia of the unattainable."

14 With postmodernism, objective reality or absolute knowledge suffers a loss of value; information becomes relative. This situation invalidates the causality and regularity principles of the scientific understanding of knowledge and undermines the validity, reliability and necessity of objective knowledge in social life. Legal relations in society are being replaced by instant lives and images where conceptualization and evaluation become insufficient and meaningless.

15 Beck underlines the necessity that everyone should have a mechanism of inquiry, awareness and control against these formations. Because the risks, threats and dangers that he says, emerged with the risk society are far more significant than they are in industrial society and no longer innocent. Beck says that these dangers cannot be perceived by the senses and cannot be determined by science.

16 When we look at the understanding of Western modernism in the early period, science is at the forefront with its methodology based on experimentation, observation and measurement. This scientific understanding, which allows an understanding and definition from singular to universal, differs from other sciences where human is at the centre. 
An important reason why postmodernists oppose the new subject is that the modern subject necessarily requires an object. ${ }^{17}$ It prevents from establishing authority over the other, suspends arbitrary relations of power associated with the category of subjects and puts an end to this implicit hierarchy. In modernity, when the subject is referred to with active and human qualities, the object is passive and treated as something (Rosenau, 1992). Most postmodernists claim that scientific classifications of people lead to objectification. The presence of a subject implies that one person is under the control of another. ${ }^{18}$

In the postmodern period, the unified structures began to erode, and the fragmentation in every area determined the functioning of postmodern politics. It can be said that with the changes in the social and economic structure in the postmodern period, the modern political institution started to transform as a whole. ${ }^{19}$ In short, this transformation emerged in the 1960s, when new values and new social movements began to emerge in Western industrial societies (Marshall, 1999). These new values and social movements have led to a new understanding of politics and political activity (Kellner, 2002).

Differences based on ethnicity, gender and age are essential sources of social identity. New social movements are formed around these identities and replace the social movements based on class. The change of the class structure resulted in the weakening of the characteristics of the classes, which are one of the essential elements of the modern period politics (Hogg and Ridgeway, 2003). Significant differences in socio-economic practices between traditional right and left parties have disappeared in this period (Brocková, 2000). In particular, the implementation of neo-liberal policies in the US and Great Britain after 1980, and the follow-up of these countries by developed and developing countries, also reduced class-based polarizations and marginalized the class-based perspective in the functioning of politics. ${ }^{20}$

As a result of the developments in the intellectual, economic and social fields in the postmodern period, the erosion of nation-states was the major structural change. According to Lash and Urry (1995), the uninhibited fluidity of capital, which is regarded as unorganized capitalism, has brought about the erosion of modern state structures, at least the change of their quality. One of the institutions in which these changes are most clearly seen is the nation-state, the political form of the modern era. Sovereignty, one of the essential qualities of the nation-states that they did not want to share with others, became a shareable asset in this period. According to Bauman, in the postmodern era, the nation-state is rapidly declining from its position as a determinant for decisions, concerning politics and society (Bauman, 1999). Because the international political system is becoming increasingly dependent on economic forces, especially hot capital, as the capital becomes global, its fluidity increases and the nation-state, which is the perpetrator of the modern era, cannot prevent this fluidity with its old structure. ${ }^{21}$

The ability of the nation-state to control capital depends on changing its structure and adapting it to the fluidity of capital. This situation brings the capital of the nation-state to its own economic decisions, especially sovereignty. However, this situation, which fosters uncertainty in political life, leads individuals to live in uneasiness at all times (Kellner, 2002). Therefore, it is difficult to speak of any certainty or guarantee for any subject in times of postmodern politics. Uncertainty has spread to almost all areas of social and political life.

\footnotetext{
17 Postmodernism, which includes an implicit criticism of modernism, has a different approach to scientific knowledge and methods. While Western modernism encapsulates scientific knowledge within its walls, interdisciplinarity comes to the forefront in the new period.

18 Postmodernism is an implicit negative criticism of modernism. Because many of the issues rejected by modernism are brought back to the agenda with the postmodern approach. This situation can be seen in many other fields of art based on real science.

19 No matter how intellectually sound it is, there is no definite and non-contested social institution that can make universal principles effective standards of universal behaviour. Instead, there are many institutions and many ethical standards that push the individual into a state of moral uncertainty with no satisfactory and reliable output.

20 A particular point to be noted here is that although postmodernism stands out as a criticism of modernism, it is not bringing any criticism to the relationship between modernism and capitalism. It provides new raw materials and markets to capitalism by taking, processing, updating and highlighting the localities in the rest of the world through postmodern approaches.

21 The term paradoxes, which are termed as modern, contain within itself. This expresses the ambiguities of modernity. On the one hand, the desire to rationalize life emerges, while on the other hand, infinite uncertainties exist. One of the consequences of modernity is that the number of moral doctrines that one can rely on increases the uncertainty.
} 


\section{Politics and Postmodernism in the Shadow of Risk Society}

An important reason for the instability and uncertainty in postmodernity is that postmodernity finds any quest for order unnecessary and meaningless. In other words, while establishing and maintaining order is perceived as a task in the modern period, the effort to establish and maintain order in the postmodern period is perceived as an unnecessary struggle (Bauman, 2001). This situation completely changes the functioning of politics. The lack of a particular order, the chaos and continuity of being in crisis bring the end of social that Baudrillard (2007) expressed. For Baudrillard (2007), this situation in the functioning of politics has been expressed in the form for a long time since the semi-sporting, semi-entertaining as a unique entertainment program.

These changes in the political field in the postmodern period were reflected in the political leadership, which is an indispensable element of political life. In short, it can be said that postmodern politics has also affected the leadership style. The modern leader, first and foremost, has an ideology-dependent nature as a requirement of modern political structure (Micewski, 2004). However, the modern leader is a visionary subject within the boundaries defined in a hierarchical structure, adopting a vertical communication style within the framework of stable relations (Machida, 2012). On the other hand, the postmodern leader is a passive subject focused on the moment, which emphasizes horizontal communication within the framework of more flexible relations with ideology. ${ }^{22}$

Another important reason for the emergence of new elements in politics and the declining elements of the modern era in the political process is the change in approaches towards ideologies in the postmodern period. In this period, ideologies were discredited, mainly and increasingly distanced from the determinants of the functioning of the political process and decision-making mechanisms (Soper, 1991). The postmodernist writers express the decline of ideological determination in the political life of the postmodern period as a feature of the postmodern situation (Lyotard, 1984).

In postmodernism, grand narratives are being replaced by small narratives, and grand theories that claim to explain everything are questioned. According to Lyotard (1984), postmodernity is the disbelief of commodity narratives, and this disbelief is a product of progress in the sciences. In the postmodernity, grand narratives are rejected, and little narratives are given priority instead..$^{23}$ In this context, postmodernism emphasizes difference and relativity by criticizing the ideologies (Machida, 2012). A grand theory is not possible in a postmodern structure because significant narratives have a comprehensive world view and envision functioning within a specific system.

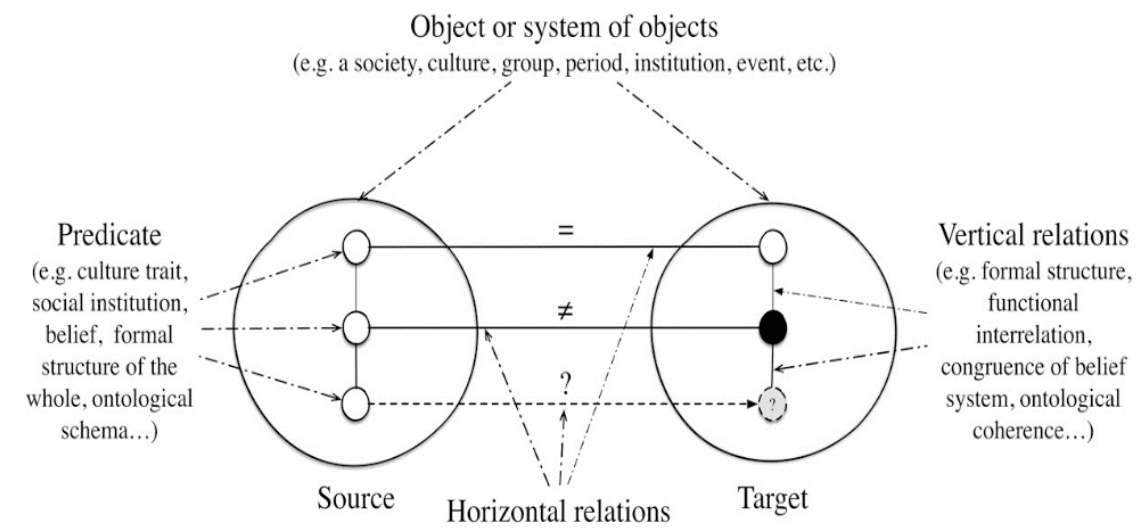

Figure 4. An Archetype of Relations Structure by Matei Candea

Source: Candea, 2018.

22 In the postmodern discourse, there is a comprehensive capitalist transformation, which can be claimed to have at least, a significant share of righteousness and can be observed based on an experiment. This transformation has caused significant changes in terms of established political knowledge theory or paradigm.

23 Another consequence of the egalitarianism of the horizontal postmodern politics is the reconsideration of old cultural identities. Their assimilation in the national framework seems to have become impossible. In addition, the opposition of postmodernism to dichotomies, such as public/private, super culture/subculture leads to the effectiveness of cultural pluralism. 
Meta or super narratives are subject to criticism because they always act in the face of problems with the potential to offer a solution. According to the postmodernist understanding, there is no evidence to suggest that these superior narratives are superior to subjective experiences (Soper, 1991). There is no difference between economic systems such as capitalism, socialism and human-based political systems, such as Marxism and Liberalism. There is no reason that they are superior or valuable than any other. ${ }^{24}$ This approach renders consistency in thought and tries to devalue value-oriented metaphors by reducing them to the same level as non-value-oriented stories or narratives. This attempt of postmodernist understanding creates the transitions, ambiguities and flexibility between institutional and permanent structures (Hutcheon, 1986). The concept of flexibility plays a significant role in revealing the difference between modernism and postmodernism.

The sovereign structures of nation-states, one of the essential features that cannot be shared with others in national borders, gradually eroded and sovereignty became shared with other elements. ${ }^{25}$ In the postmodern period, the final position of the nation-state in decision-making processes has been greatly shaken (He, 2012). The final position began to be transferred to the elements operating outside the political sphere, especially to the economic elements. This situation makes the national and international political space dependent on economic structures, especially to fluid capital (Moraru, 2001).

As the capital becomes fluid and moves freely on a global level, the nation-state, which is the subject of the modern era and relatively free in policymaking, is forced to change its quality and take a form suitable for fluid capital. In this context, the fact that the nation-state structure holds capital seems to depend on the change of its classical structure. This structural change necessitates the inclusion of capital in many of the policies of the nation-state, which are closely linked to the sovereign structure, particularly economic policy (Giroux, 1991). This situation narrowed the field of action of the nation-state, especially the field of power and forced the nation-state to produce flexible policies. Therefore, the nation-state rapidly lost its position as a determinant and regulator. The global network of relations and interactions that cross local, regional and national boundaries weaken social ties and loyalty by becoming deterministic and regulating.

In the postmodern period, the establishment of a flexible organization within a consumer-oriented market structure in the economic field, the promotion of privatizations within the framework of neoliberal policies come to the fore (Perelman, 2015). These policies and practices are also important determinants of social and economic relations. First of all, these policies and practices play a crucial role in the emergence of flexible relations at the socio-economic level (Cochran, 1995). Flexible relations that emerge at the social level lead to the formation of the postmodern leader within the framework of flexible relations. In this context, it is seen that the postmodern leader is in a more sensitive and harmonious approach to social developments rather than being a leader who shapes society. ${ }^{26}$

In traditional and modern leadership, the leader of postmodern times is in a passive position, and the one who is trying to change is not affected, while the leader change individuals, groups or the whole society in the position of agent and active subject (Heller and Feher, 1988). When we look at the societies experiencing postmodernity, it is seen that flexibility among the characteristics of the political leaders' election successes and political practices are considered, these leaders try to act within flexible relations, develop policies according to cyclical requirements and provide more flexible space instead of using a sharp language to limit the spheres of action. ${ }^{27}$ They prefer political discourse (Goodchild, 1990). In this context, it can be said that flexibility is a common feature of the postmodern political leaders.

\footnotetext{
24 Liberal thought and state understanding in postmodern politics have adopted diversity, pluralism and participation, and presented the idea of creating a new political culture in a globalizing world. Postmodernists reinforce the existence of minorities, reject nationalism, emphasize ethnic differences, and do not accept integrative and unifying elements, such as the unity of language and religion. They support their ideas with the liberal state approach that they adopt.

25 Postmodern society is a rapidly changing society. Technology and knowledge form the basis of social organization, and the similarity of knowledge across the world, and the similarity that uses the same language and writing create a unity. Because of the developments in the field of communication, people of different societies started to use the same codes. However, this situation pushes the boundaries of the national state, and makes it difficult for people to find their place and identity.

26 In the postmodern period, uncertainty, partiality, change of concepts, lack of similarities, pluralism, fragmentation and multiculturalism emerge. With the popularizing idea of multiculturalism, the nation-state approaches were damaged.

27 Postmodernist thinkers are opposed to the concept of nationality since the nation is an imaginary community and sociality is not integrable. The community approach based on ethnic and religious identities is the rejection of the national society and the state. According to postmodernism, after the nation-state has been overcome, localization and regionalization are the proofs of the agenda.
} 
The characteristics of current postmodern leadership are quite different from each other. The modern leader is acting with long-term planning. He/She has a holistic character settled over a long period and he/she tries to act with moral responsibility. He/She is an expert in the field of society (Turnbull, 2010). That is an active subject trying to transform within the framework. ${ }^{28}$ However, the modern political leader is also an individual who is intelligent, charismatic, attaches importance to the hierarchy and subordinates the superiors within the framework of strict relations, but also gives up his interests for the benefit of society and acts with the sense of us (Reiner, 1992).

\section{CONCLUSION}

Along with the changes in the social and economic structures, affecting the sovereignty of the nation-states in the postmodern period, the political structure that dominated the modern period has also undergone a significant transformation. This transformation emerged primarily in the 1960s with the beginning of the formation of new values and new social movements in Western industrial societies. These new social movements which are distinct from economic-based social class movements are decentralized, disorganized and fragmented. These social movements are deprived of a coherent organizational structure, following the postmodern understanding. They cannot follow long-term strategies due to the uncertain nature of the postmodern era. Consequently, in the postmodern period, ideologies have also been discredited and significantly distanced from their positions. In the postmodern understanding, ideologies and super narratives are replaced by small narratives with an extreme emphasis on relativity and difference.

However, the fragmentation experienced in all spheres of life, especially in the advanced capitalist countries and in the secular Western societies, living in the postmodern era, has also fed this transitivity and flexibility. Therefore, especially in advanced capitalist countries and secular societies, the value that started to dominate in almost every area was flexibility. This concept plays a functional role in defining the postmodern period as it shows that there is no place for rigidity in the postmodern period.

The fact that the concept of flexibility prevails the reflection of the political leadership in the postmodern period. Because societies have similar structures, the governors of societies have the same structure as well. Accordingly, postmodern political leadership is shaped by the society. The postmodern leader shapes his discourse in the light of the data about the social preferences that he obtains from various public surveys and that changes his policies accordingly. In this context, contrary to the traditional and modern understanding of leadership, which tries to shape the society within a comprehensive narrative, the postmodern leader seems to adapt the changing conditions and shows flexibility in the face of social demands. The traditional and modern leaders of course, have flexible attitudes within specified limits. However, this flexibility is not the rule but the exception as in the postmodern era.

Given the current postmodern situation that lets the political sphere to be controlled by global capitalism, instead of an active agent, reveals a situation that leaves society as a whole unsettled and lacking trust. This situation feeds the crises in all areas of life, including the social, political, cultural and economic spheres. In this context, to minimize crises, uncertainty and chaos that prevail the postmodern period are dominated by the trust and loyalty that the political leader needs. In construction such an environment, leaders who are in front of individuals, try to draw a specific direction to society.

In this respect, the political leader of the postmodern era should direct the masses, motivate them within the framework of a specific project, and at the same time, make them a part of his/her projects. In the postmodern era, the political sphere requires political leaders who emphasize their leadership skills, attach greater importance to intellectual capital, carefully follow global developments and achieve legitimate social expectations through using communication tools effectively. Such a political leadership requires some harmony between the charismatic leadership approach and the transformational leadership approach.

28 A postmodern politics and political culture express dissatisfaction with modern politics, bureaucracy, loyalty, discipline, authority and mechanism. Freedom, difference and heterogeneity are highly emphasized instead. Issues, such as identity and locality are re-addressed. New models, such as radical and negotiating democracy emerged because of the quest of postmodernism. 


\section{Pamukkale Üniversitesi Sosyal Bilimler Enstitüsü Dergisi, Sayı 44, Mayıs 2021 V. Güntay}

\section{Bibliography}

Alexander, J. \& Smith, P. (1996). "Social Science and Salvation: Risk Society as Mythical Discourse", Zeitschrift Für Soziologie, 25/4, 251-262. Retrieved from www.jstor.org/stable/23771807

Aronowitz, S. (1987). "Postmodernism and Politics", Social Text, 18, 99-115. doi:10.2307/488695

Atkinson, E. (2002). "The Responsible Anarchist: Postmodernism and Social Change", British Journal of Sociology of Education, 23/1, 73-87. Retrieved from www.jstor.org/stable/1393098

Baudrillard, J. (1998). The Consumer Society, Myths and Structures, London: SAGE Publications.

Baudrillard, J. (2007). In the Shadow of The Silent Majorities, Los Angeles: Semiotext(e).

Bauman, Z. (1999). In Search of Politics, Cambridge: Polity Press.

Bauman, Z. (2001). The Individualized Society, Cambridge: Polity Press.

Bauman, Z. (2007). Modernity and Ambivalence, Cambridge: Polity Press.

Beck, U. (1992a). Risk Society: Towards a New Modernity, Los Angeles: SAGE Publications.

Beck, U. (1992b). World Risk Society, Cambridge: Polity Pres.

Beck, U. (2000). What is Globalization? Cambridge: Polity Press.

Beck, U. (2005). The Reinvention of Politics: Rethinking Modernity in The Global Social Order, Cambridge: Polity Press.

Best, S. \& Kellner, D. (1991). Postmodern Theory: Critical Interrogations, New York: The Gulford Press.

Brocková, I. (2000). “Challenge of Globalization, American Dilemma”, Medzinárodné Otázky, 9/1, 5-27. Retrieved from www.jstor.org/stable/44963299

Candea, M. (2018). Comparison in Anthropology: The Impossible Method, Cambridge: Cambridge University Press.

Cochran, M. (1995). "Postmodernism, Ethics and International Political Theory", Review of International Studies, 21/3, 237-250. Retrieved from www.jstor.org/stable/20097411

Di Leo, J. (2001). "Whose Theory, Which Globalism? Notes on the Double Question of Theorizing Globalism and Globalizing Theory", Symplokē, 9/1-2, 7-14. Retrieved from www.jstor.org/stable/40550498

Fotopoulos, T. (2001). "The Myth of Postmodernity. Democracy \& Nature", 7/1, 27-75. Retrieved from https:// www.tandfonline.com/doi/abs/10.1080/10855660020045143

Giddens, A. (1990). The Consequences of Modernity, Stanford: Stanford University Press.

Giddens, A. (1992). The Transformation of Intimacy, Stanford: Stanford University Press.

Giroux, H. (1991). "Border Pedagogy and the Politics of Modernism/Postmodernism", Journal of Architectural Education, 44/2, 69-79. doi:10.2307/1425099

Goodchild, B. (1990). "Planning and the Modern/Postmodern Debate", The Town Planning Review, 61/2, 119137. Retrieved from www.jstor.org/stable/40112887

He, C. (2012). Modernization Science, Berlin: Springer.

He, C. (2015, September 23). Religion, Culture and Cultural Modernization. Retrieved from http:// en.modernization.ac.cn/document.action?docid=29939

Heller, A. \& Feher, F. (1988). The Postmodern Political Condition, Columbia: Columbia University Press.

Hirst, P. \& Thompson, G. (1999). Globalization in Question, Cambridge: Polity Press.

Hobsbawm, E. (2008). Globalisation, Democracy and Terrorism, Boston: Little, Brown Book Group.

Hogg, M. \& Ridgeway, C. (2003). "Social Identity: Sociological and Social Psychological Perspectives", Social Psychology Quarterly, 66/2, 97-100. Retrieved from www.jstor.org/stable/1519841

Hoy, T. (1993). “Derrida: Postmodernism and political Theory", Philosophy \& Social Criticism, 19/3-4, 243-260. Retrieved from https://doi.org/10.1177/019145379301900302

Hutcheon, L. (1986). "The Politics of Postmodernism: Parody and History", Cultural Critique, 5, $179-207$. doi:10.2307/1354361 
Huyssen, A. (2006). "Introduction: Modernism after Postmodernity", New German Critique, 99, 1-5. Retrieved from www.jstor.org/stable/27669174

Jameson, F. (1991). Postmodernism or, The Cultural Logic of Late Capitalism, Durham: Duke University Press.

Kellner, D. (2002). "Theorizing Globalization”, Sociological Theory, 20/3, 285-305. Retrieved from www.jstor.org/ stable/3108613

Lash, S. \& Urry, J. (1995). The End of Organized Capitalism, Oxford: Polity Press.

Libman, B. (2019, November 4) Capital Realism, Ten Years On. Retrieved from http://politicsslashletters.org/ commentary/capitalist-realism-ten-years-on/

Lyotard, J. (1984). The Postmodern Condition: A Report on Knowledge, Manchester: Manchester University Press.

Machida, S. (2012). “Does Globalization Render People More Ethnocentric? Globalization and People's Views on Cultures", The American Journal of Economics and Sociology, 71/2, 436-469. Retrieved from www.jstor.org/ stable/23245230

Marshall, B. (1999). "Globalisation, Environmental Degradation and Ulrich Beck's Risk Society”, Environmental Values, 8/2, 253-275. Retrieved from www.jstor.org/stable/30301706

Matthewman, S. \& Hoey, D. (2006). “What Happened to Postmodernism?” Sociology, 40/3, 529-547. Retrieved from www.jstor.org/stable/42856869

Micewski, E. (2004). "The Education Of (Military) Leadership Personnel in A Postmodern World”, Connections, 3/1, 67-74. Retrieved from www.jstor.org/stable/26323022

Miller, T. (2014). Modernism and The Frankfurt School, Edinburgh: Edinburgh University Press.

Mirchandani, R. (2005). "Postmodernism and Sociology: From the Epistemological to the Empirical”, Sociological Theory, 23/1, 86-115. Retrieved from www.jstor.org/stable/4148895

Mittelman, J. (2004). "What is Critical Globalization Studies?” International Studies Perspectives, 5/3, 219-230. Retrieved from www.jstor.org/stable/44218323

Moraru, C. (2001). "The Global Turn in Critical Theory", Symplokē, 9/1-2, 74-82. Retrieved from www.jstor.org/ stable/40550501

Perelman, M. (2015). "The Anarchy of Globalization: Local and Global, Intended and Unintended Consequences", World Review of Political Economy, 6/3, 352-374. doi:10.13169/worlrevipoliecon.6.3.0352

Reiner, R. (1992). "Policing a Postmodern Society", The Modern Law Review, 55/6, 761-781. Retrieved from www.jstor.org/stable/1096856

Rosenau, P. M. (1992). Post-modernism and The Social Sciences, Princeton: Princeton University Press.

Seethi, K. (2001). “Postmodernism, Neoliberalism and Civil Society: A Critique of the Development Strategies in the Era of Globalisation", The Indian Journal of Political Science, 62/3, 307-320. Retrieved from www.jstor. org/stable/42771344

Soper, K. (1991). “Postmodernism and Its Discontents”, Feminist Review, 39, 97-108.

Thompson, S. C. (2018). "Expanding Modernism: A Review of Peter Kalliney's Modernism in a Global Context”, Journal of Modern Literature, 41/2, 165-170.

Turnbull, N. (2010). "Introduction: Postmodernism and Rationality", Revue Internationale De Philosophie, 64/2511, 5-7. Retrieved from www.jstor.org/stable/23961019

Tushnet, M. (1995). "Postmodernism and Democracy", American Literary History, 7/3, 582-590. Retrieved from www.jstor.org/stable/489853

Van Loon, J. (2003). Risk and Technological Culture: Towards a Sociology of Virulence, London: Routledge.

Williams, M. (2008). "(In)Security Studies, Reflexive Modernization and the Risk Society", Cooperation and Conflict, 43/1, 57-79. Retrieved from www.jstor.org/stable/45084567 


\section{Beyan ve Açıklamalar (Disclosure Statements)}

1. Bu çalışmanın yazarları, araştırma ve yayın etiği ilkelerine uyduklarını kabul etmektedirler (The authors of this article confirm that their work complies with the principles of research and publication ethics).

2. Yazarlar tarafından herhangi bir çıkar çatışması beyan edilmemiştir (No potential conflict of interest was reported by the authors).

3. Bu çalışma, intihal tarama programı kullanılarak intihal taramasından geçirilmiştir (This article was screened for potential plagiarism using a plagiarism screening program). 